\author{
SANDIA REPORT \\ SAND2011-3026 \\ Unlimited Release \\ Printed May 2011
}

\title{
Development of a Micro Flow-Through Cell for High Field NMR Spectroscopy
}

\author{
Todd M. Alam and Sarah K. McIntyre
}

Prepared by

Sandia National Laboratories

Albuquerque, New Mexico 87185 and Livermore, California 94550

Sandia National Laboratories is a multi-program laboratory managed and operated by Sandia Corporation, a wholly owned subsidiary of a Lockheed Martin Corporation, for the United States

Department of Energy's National Nuclear Security Administration under Contract DE-AC04-94AL85000.

Approved for public release; further dissemination unlimited. 
Issued by Sandia National Laboratories, operated for the United States Department of Energy by Sandia Corporation.

NOTICE: This report was prepared as an account of work sponsored by an agency of the United States Government. Neither the United States Government, nor any agency thereof, nor any of their employees, nor any of their contractors, subcontractors, or their employees, make any warranty, express or implied, or assume any legal liability or responsibility for the accuracy, completeness, or usefulness of any information, apparatus, product, or process disclosed, or represent that its use would not infringe privately owned rights. Reference herein to any specific commercial product, process, or service by trade name, trademark, manufacturer, or otherwise, does not necessarily constitute or imply its endorsement, recommendation, or favoring by the United States Government, any agency thereof, or any of their contractors or subcontractors. The views and opinions expressed herein do not necessarily state or reflect those of the United States Government, any agency thereof, or any of their contractors.

Printed in the United States of America. This report has been reproduced directly from the best available copy.

Available to DOE and DOE contractors from

U.S. Department of Energy

Office of Scientific and Technical Information

P.O. Box 62

Oak Ridge, TN 37831

Telephone: $\quad$ (865) 576-8401

Facsimile: (865) 576-5728

E-Mail: reports@adonis.osti.gov

Online ordering: http://www.osti.gov/bridge

Available to the public from

U.S. Department of Commerce

National Technical Information Service

5285 Port Royal Rd.

Springfield, VA 22161

Telephone: $\quad$ (800) 553-6847

Facsimile: (703) 605-6900

E-Mail: $\quad$ orders@ntis.fedworld.gov

Online order: $\quad$ http://www.ntis.gov/help/ordermethods.asp?loc=7-4-0\#online

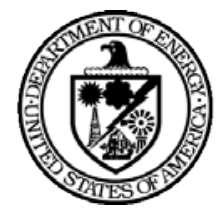




\title{
SANDIA REPORT
}

SAND2011-3026

Unlimited Release

Printed May 2011

\section{Development of a Micro Flow-Through Cell for High Field NMR Spectroscopy}

\author{
Todd M. Alam and Sarah K. McIntyre \\ Department of Electronic \& Nanostructured Materials \\ Sandia National Laboratories \\ P.O. Box 5800 \\ Albuquerque, New Mexico 87185
}

\begin{abstract}
A highly transportable micro flow-through detection cell for nuclear magnetic resonance (NMR) spectroscopy has been designed, fabricated and tested. This flow-through cell allows for the direct coupling between liquid chromatography (LC) and gel permeation chromatography (GPC) resulting in the possibility of hyphenated LC-NMR and GPC-NMR. The advantage of the present flow cell design is that it is independent and unconnected to the detection probe electronics, is compatible with existing commercial high resolution NMR probes, and as such can be easily implemented at any NMR facility. Two different volumes were fabricated corresponding to between $\sim 3.8$ and $10 \mu \mathrm{L}$ detection volume. Examples of the performance of the cell on different NMR instruments, and using different NMR detection probes were demonstrated.
\end{abstract}




\section{Acknowledgements}

The authors acknowledge support of the Sandia RTFB program, and Rand Garfield for machining of selected parts.

Sandia National Laboratories is a multi-program laboratory operated by Sandia Corporation, a wholly owned subsidiary of Lockheed Martin company, for the U. S. Department of Energy’s National Nuclear Security Administration. 


\section{TABLE OF CONTENTS}

\section{Contents}

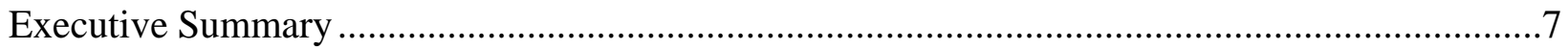

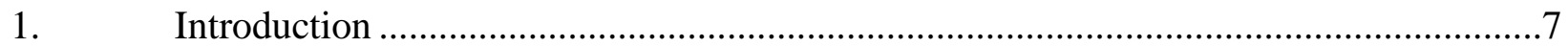

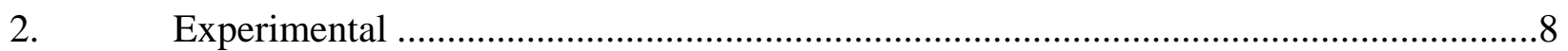

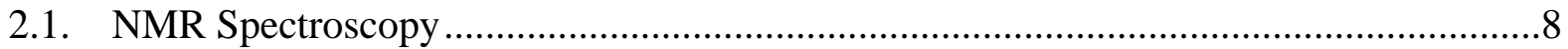

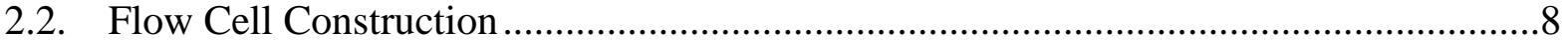

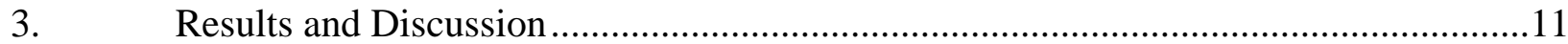

3.1. Flow Cell Detection Volume Determination .........................................................11

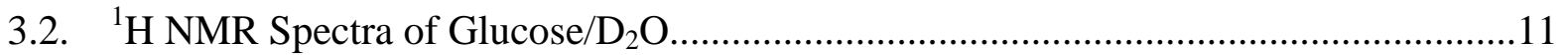

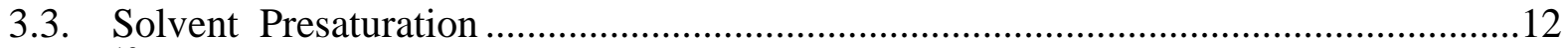

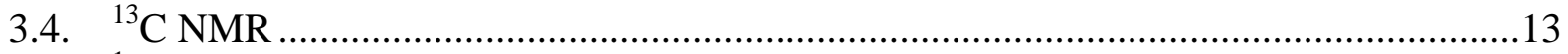

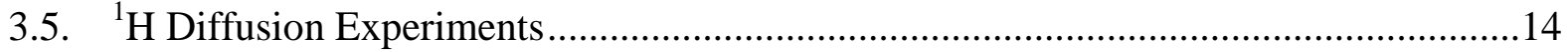

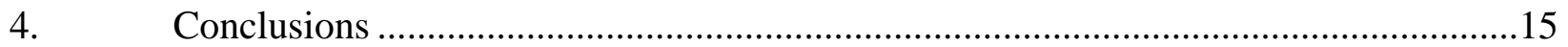

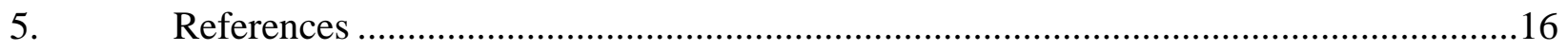

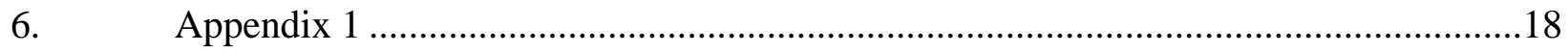

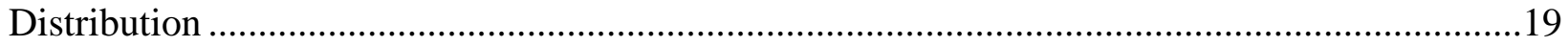

\section{LIST OF FIGURES}

Figure 1: Drawing showing the construction and layout of the theta-capillary micro flow cell.... 9

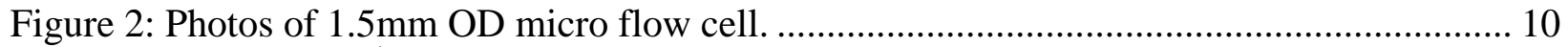

Figure 3: Summary of ${ }^{1} \mathrm{H}$ NMR data collected from flow cells. .............................................. 12

Figure 4: Comparison of ${ }^{1} \mathrm{H}$ NMR spectra acquired with presaturation..................................... 13

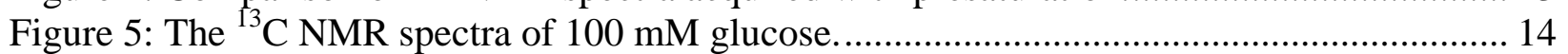

Figure 6: ${ }^{1} \mathrm{H}$ NMR $600 \mathrm{MHz}$ spectra as a function of gradient strength . ................................ 15 


\section{Nomenclature}

DOE Department of Energy

SNL Sandia National Laboratories

NMR Nuclear Magnetic Resonance

GPC Gel Permeation Chromatography

NW

Nuclear Weapons 


\section{Development of a Micro Flow-Through Cell for High Field NMR Spectroscopy}

\section{Executive Summary}

This report describes the initial efforts at coupling gel permeation chromatography with nuclear magnetic resonance (GPC-NMR) [1-4] to study polymer production and aging effects under the RTFB program. A micro flow-through cell has been developed that allows very small volumes to be detected by NMR along with the possibility of monitoring of a continuous flow. One of the goals of this effort was the design of a flow-through NMR cell that could be easily transported and utilized in different facilities, including any NMR laboratory in the NW complex regardless of the field strength or equipment manufacturer or vintage. This requirement is realized using the novel micro flow-through NMR cell described here.

\section{Introduction}

Nuclear magnetic resonance (NMR) spectroscopy continues to be a powerful analytical tool in the identification and characterization of chemical species. Recent advances in hyphenated NMR techniques including combination with gel permeation chromatography (GPCNMR), liquid chromatography (LC-NMR), supercritical fluid chromatography (SFC-NMR), solid phase extraction (SPE-LC-NMR), flow injection analysis (FIA-NMR), high pressure liquid chromatography (HPLC-NMR), capillary liquid chromatorgraphy (capLC-NMR) and liquid chromatography mass spec (LC-MS-NMR) now allow very complex problems to be explored.[517] For hyphenated NMR techniques, either a flow-through cell or a specialized NMR probe is utilized that allows the effluent stream from the LC or GPC to flow directly through the detection coil of the NMR spectrometer.

Initial micro NMR flow cells ranged from 60 to $220 \mu \mathrm{L}$ in volume and commonly required the modification of probes to allow the transport of solutions in and out of the active volume.[4-5, 18-19] while later dedicated micro probes have reduced this volume to tens of $\mu \mathrm{L}$ amounts.[17, 20-21] More recently a NMR microchip "MICCS” (Micro Channeled Cell for 
Synthesis monitoring) probe has been reported that allowed for the real time monitoring of chemical reactions.[22] This MICCS probe uses a microchip in which channels have been fabricated, but has the distinct advantage of being directly used in a standard $5 \mathrm{~mm}$ solution probes without any modifications. We have borrowed on this concept to develop the micro flowcell described here, but have elected to use easily obtainable commercial micro-capillaries in the cell design.

\section{Experimental}

\subsection{NMR Spectroscopy}

The high resolution ${ }^{1} \mathrm{H}$ NMR experiments were performed using a 5mm broadband (BB) and a 5mm inverse triple resonance (TXI) probe on a Bruker DRX 400 operating at $399.87 \mathrm{MHz}$, or on a Bruker Avance 600, using a 5mm broadband (BB) probe, and operating at $600.14 \mathrm{MHz}$. The high resolution ${ }^{13} \mathrm{C}$ NMR spectra were obtained on the higher field instrument at $150.92 \mathrm{MHz}$, using standard single pulse Bloch decay with WALTZ-16 ${ }^{1} \mathrm{H}$ decoupling. For the ${ }^{1} \mathrm{H}$ NMR spectra at both fields solvent presaturation was obtained using a frequency modulated low power pulse sequence with GARP ${ }^{13} \mathrm{C}$ decoupling.[23] The ${ }^{1} \mathrm{H}$ DOSY experiments were performed on the Avance 600 using a stimulated echo with a $1 \mathrm{~ms}$ gradient pulse on a DIFF30 diffusion probe with $1000 \mathrm{G} / \mathrm{cm}$ gradients. Standard acquisition conditions for ${ }^{1} \mathrm{H}$ were typically: $4 \mathrm{~s}$ recycle delay, 16 to 64 scan averages, $64 \mathrm{~K}$ complex points, zero-filled to $64 \mathrm{~K}$ points; solvent presaturation experiments employed a $100 \mathrm{~ms}$ shaped presaturation pulse. The ${ }^{13} \mathrm{C}$ spectra were acquired with a $10 \mathrm{~s}$ recycle delay and 5k scan averages.

\subsection{Flow Cell Construction}

The flow cells (see Appendix 1 for technical drawings) consisted of a 1.5 or $2.0 \mathrm{~mm}$ outer diameter (OD) split-theta capillary glass (Harvard Apparatus, Holliston, MA) closed on the lower end with a polyetheretherketone (PEEK) cap machined internally to allow flow from one side of the split capillary to the other. The outside diameter of the PEEK cap is machined to fit snugly in a standard 5mm NMR tube. A piece of $360 \mu \mathrm{m}$ OD $(150 \mu \mathrm{m}$ ID) PEEK tubing (IDEX/Upchurch, Oak Harbor, WA) was glued using Norland Optical Adhesive 76 (Norland, Cranbury, NJ) into separate channels of the theta-capillary allowing for sample transport in and 
out. This adhesive was cured at $50^{\circ} \mathrm{C}$ for approximately 12 hours after initial curing in a UV reactor. Other epoxies were explored, but all showed considerable loss of function with exposure to tetrahydrofuran (THF) carrier solvent. A second piece of machined PEEK was glued slightly below the attachment point of the $360 \mu \mathrm{m}$ tubing to the capillary to further support the flow cell when placed in a 5mm NMR tube. This PEEK support, as well as the lower PEEK cap, was grooved to allow solvent flow around it. In this manner it was possible to place deuterated solvent around the inner capillary to assist in shimming if required. Figure 1 shows a schematic of this cell design, while Figure 2 shows the constructed cell inside and outside the outer NMR tube.

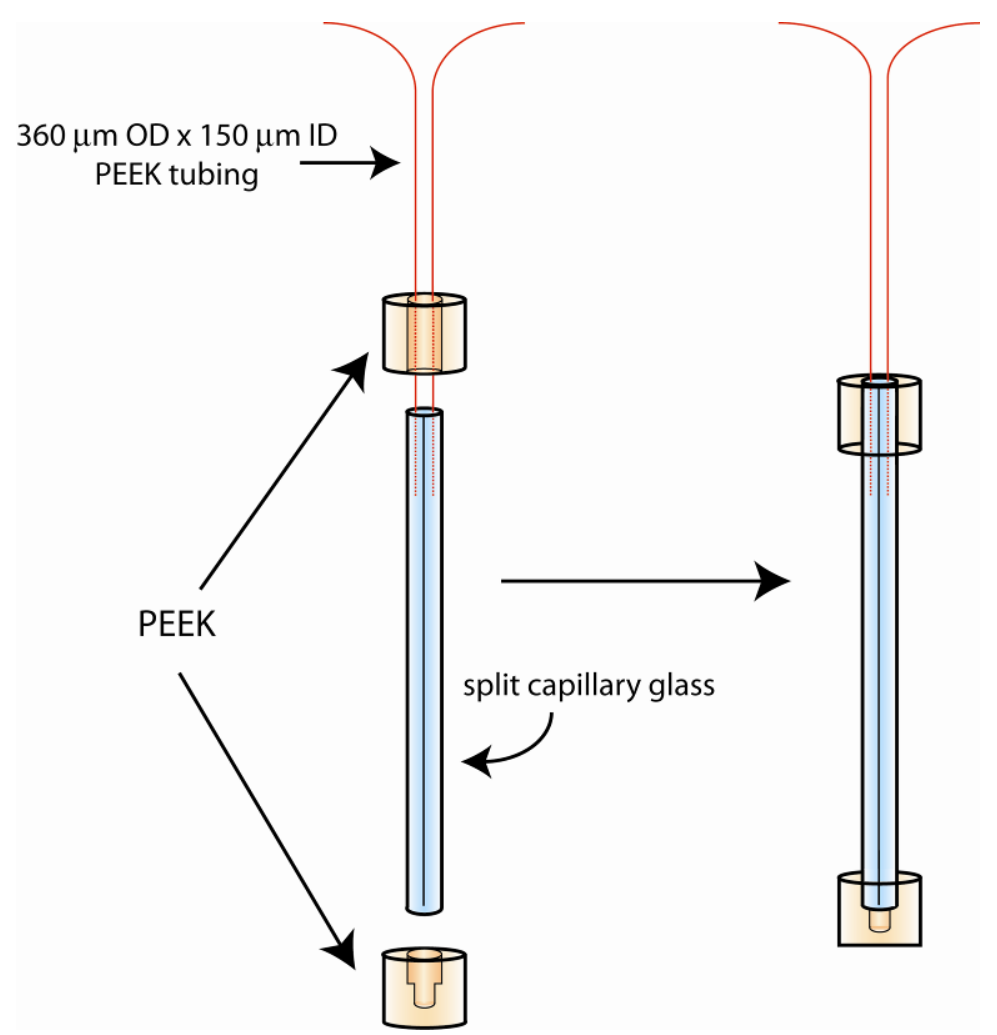

Figure 1: Drawing showing the construction and layout of the theta-capillary micro flow cell.

This constructed flow cell was then carefully slid into a standard $5 \mathrm{~mm}$ NMR tube, inserted into a spinner assembly and lowered into the NMR magnet with the transport PEEK tubing exiting through the upper end of the transport shuttle/shim tube. All experiments were performed in a non-spinning mode due to the presence of the PEEK tubing. 


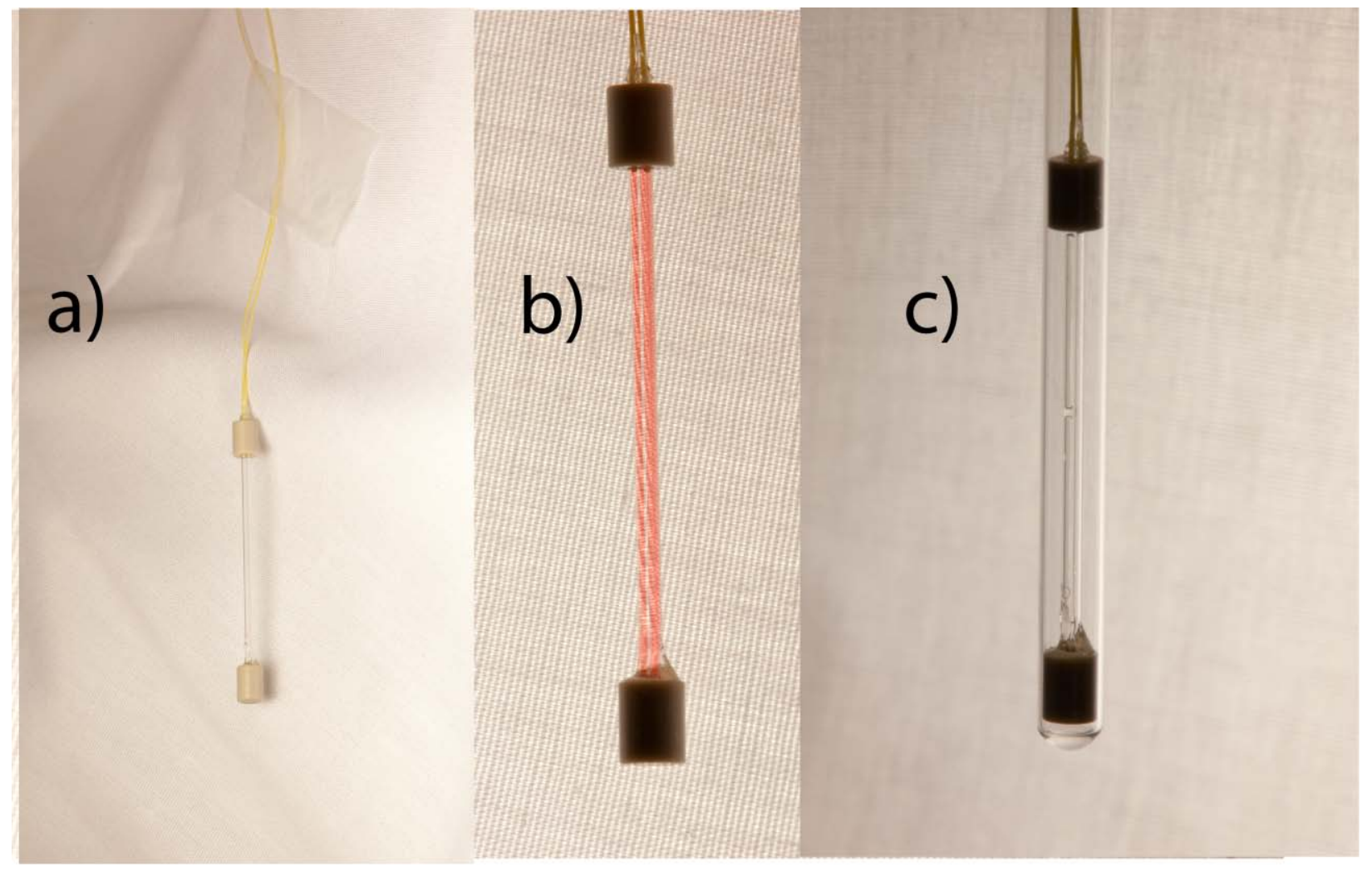

Figure 2: Photos of $1.5 \mathrm{~mm}$ OD micro flow cell. a) unfilled flow cell. b) filled flow cell to show split capillary. c) flow cell situated inside a standard 5mm NMR tube.

To introduce sample flow to the micro NMR cell, a 1/16" to $360 \mu \mathrm{m}$ adapter was attached to one end of the flow cell $360 \mu \mathrm{m}$ tubing. The $1 / 16$ " end of the adapter was attached to a Hamilton Gastight syringe modified with a Hamilton compression fitting to accept 1/16” tubing in the needle port. The total volume of the flow cell fabricated with $1.5 \mathrm{~mm}$ OD capillary glass was $\sim 24 \mu \mathrm{L}$, corresponding to a detection volume of $\sim 10 \mu \mathrm{L}$. The total volume of the cell fabricated with $2.0 \mathrm{~mm}$ OD capillary glass was $\sim 40 \mu \mathrm{L}$, with a detection volume of $\sim 20 \mu \mathrm{L}$. For the NMR results presented here, the micro flow cell was filled with $100 \mathrm{mM}$ glucose in $\mathrm{D}_{2} \mathrm{O}$ (containing 1\% w/w DSS, 4,4-dimethyl-4-silapentane-1-sulfonic acid). The area inside the NMR tube surrounding the cell was filled with $\mathrm{D}_{2} \mathrm{O}$ (neat) unless otherwise noted. 


\section{Results and Discussion}

\subsection{Flow Cell Detection Volume Determination}

While the total volume of the $1.5 \mathrm{~mm}$ and $2.0 \mathrm{~mm}$ OD capillary glass flow cells were 24 $\mu \mathrm{L}$ and $40 \mu \mathrm{L}$, respectively, the actual detection volume for these cell is determined by the length of the particular coil in the probe utilized. The calculated detection volumes for the 1.5 $\mathrm{mm}$ and $2.0 \mathrm{~mm}$ micro flow cells with the four different NMR probes employed in this work are summarized in Table 1.

Table 1. Detection volumes $(\mu \mathrm{L})$ by probe (percentage of the detection volume for a $5 \mathrm{~mm}$ standard tube).

\begin{tabular}{|l|l|l|l|l|}
\hline $\begin{array}{l}\text { Flow cell } \\
\text { OD (mm) }\end{array}$ & 400 MHz BB & 400 MHz TXI & 600 MHz BB & 600 MHz diffusion \\
\hline 1.5 & $3.8 \mu \mathrm{L}(16.0 \%)$ & $3.8 \mu \mathrm{L}(15.7 \%)$ & $3.8 \mu \mathrm{L}(16.0 \%)$ & $3.8 \mu \mathrm{L}(16.0 \%)$ \\
\hline 2.0 & $10.7 \mu \mathrm{L}(26.7 \%)$ & $10.7 \mu \mathrm{L}(26.3 \%)$ & $10.7 \mu \mathrm{L}(26.7 \%)$ & $10.7 \mu \mathrm{L}(26.7 \%)$ \\
\hline
\end{tabular}

\section{2. ${ }^{1} \mathrm{H}$ NMR Spectra of Glucose/ $\mathrm{D}_{2} \mathrm{O}$ Solution}

To address and compare the performance of these micro flow cells in different probe configurations, ${ }^{1} \mathrm{H}$ NMR spectra of $100 \mathrm{mM}$ glucose in $\mathrm{D}_{2} \mathrm{O}$ (containing $1 \% \mathrm{w} / \mathrm{w}$ DSS) were obtained from each flow cell under a variety of instrumental configurations. In particular the impact of possible susceptibility effects on shimming performance were to be addressed Spectra from the $1.5 \mathrm{~mm}$ flow cell were acquired on 400 and $600 \mathrm{MHz}$ NMR instruments, using a $5 \mathrm{~mm}$ broadband probe for experiments at $400 \mathrm{MHz}$, and 5mm broadband and diffusion probes for experiments at $600 \mathrm{MHz}$. Spectra from the $2.0 \mathrm{~mm}$ flow cell were acquired at $400 \mathrm{MHz}$ with $5 \mathrm{~mm}$ broadband and inverse probes. The spectra collected in these experiments are summarized in Figure 3. These results show that similar performance was obtained using the different commercial NMR probes, with the predicted change in sensitivity and resolution performance resulting from changing magnetic field strength dominating the differences. 

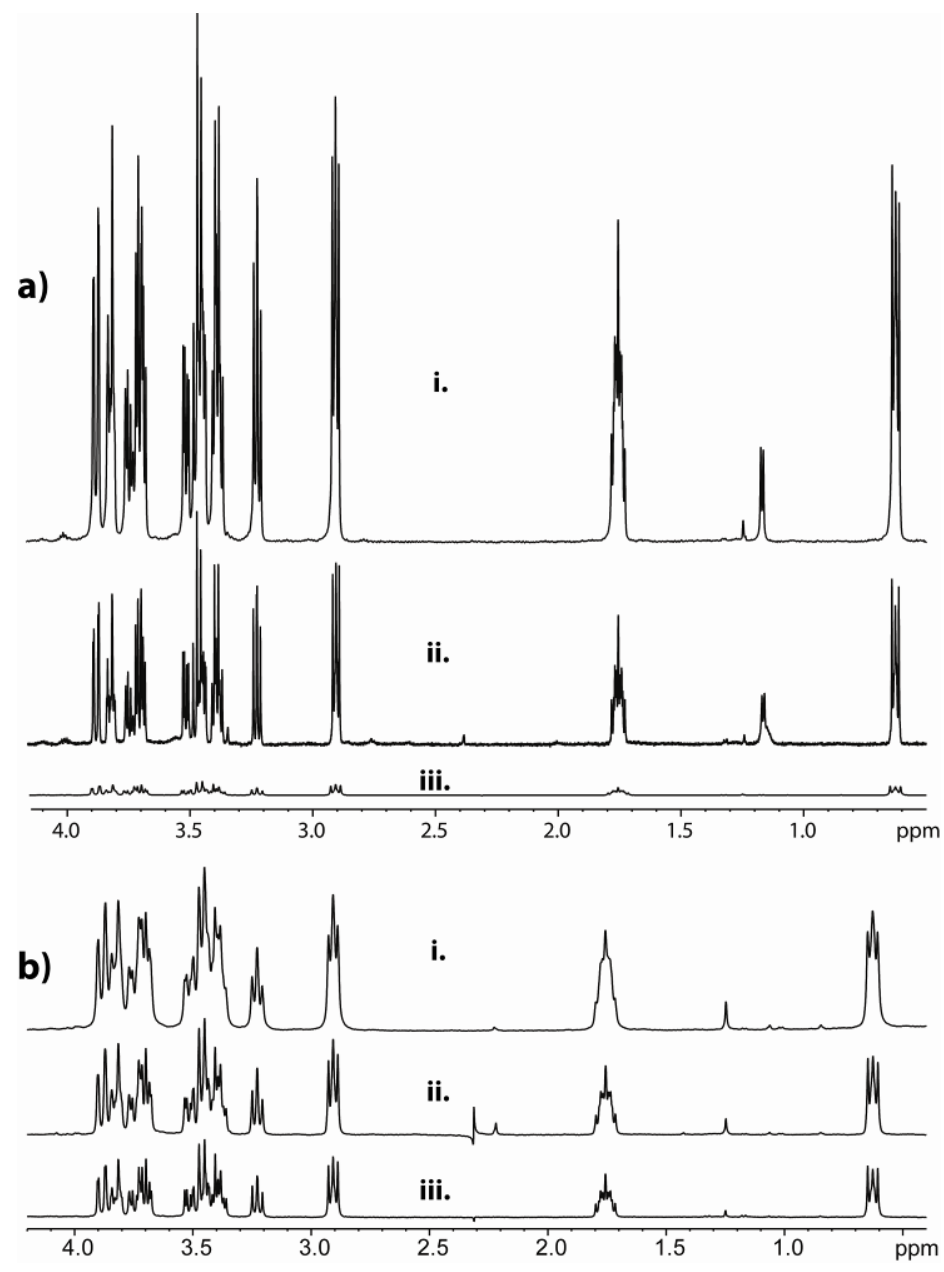

Figure 3: Summary of ${ }^{1} \mathrm{H}$ NMR data collected from $1.5 \mathrm{~mm}$ OD and $2.0 \mathrm{~mm}$ OD flow cells; a) comparison of data collected from $1.5 \mathrm{~mm}$ OD cell: i. $600 \mathrm{MHz}$ broadband probe, ii. $600 \mathrm{MHz}$ diffusion probe, iii. $400 \mathrm{MHz}$ broadband probe; b) comparison of data collected from $2.0 \mathrm{~mm}$ OD and $1.5 \mathrm{~mm}$ OD flow cells: i., $2.0 \mathrm{~mm}$ OD cell, $400 \mathrm{MHz}$ TXI probe, ii., $2.0 \mathrm{~mm}$ OD flow cell, 400 $\mathrm{MHz}$ broadband probe, iii., $1.5 \mathrm{~mm}$ OD cell, $400 \mathrm{MHz}$ broadband probe.

\subsection{Solvent Presaturation}

For flow application in hyphenated techniques it is necessary to remove the dominant carrier solvent resonance, even in cases using deuterated solvents. To test the performance of solvent presaturation using these micro flow cells, ${ }^{1} \mathrm{H}$ NMR spectra of $100 \mathrm{mM}$ glucose were acquired, applying selective saturation to the dominant $\mathrm{H}_{2} \mathrm{O} / \mathrm{HDO}$ resonance. Comparison of presaturated and standard spectra from each flow cell (Figure 4), clearly demonstrate that the flow cell approach to NMR analysis of low-concentration, small-volume samples in protonated solvents (or very exchangeable solvents, like $\mathrm{D}_{2} \mathrm{O}$ ) is feasible. 
a)
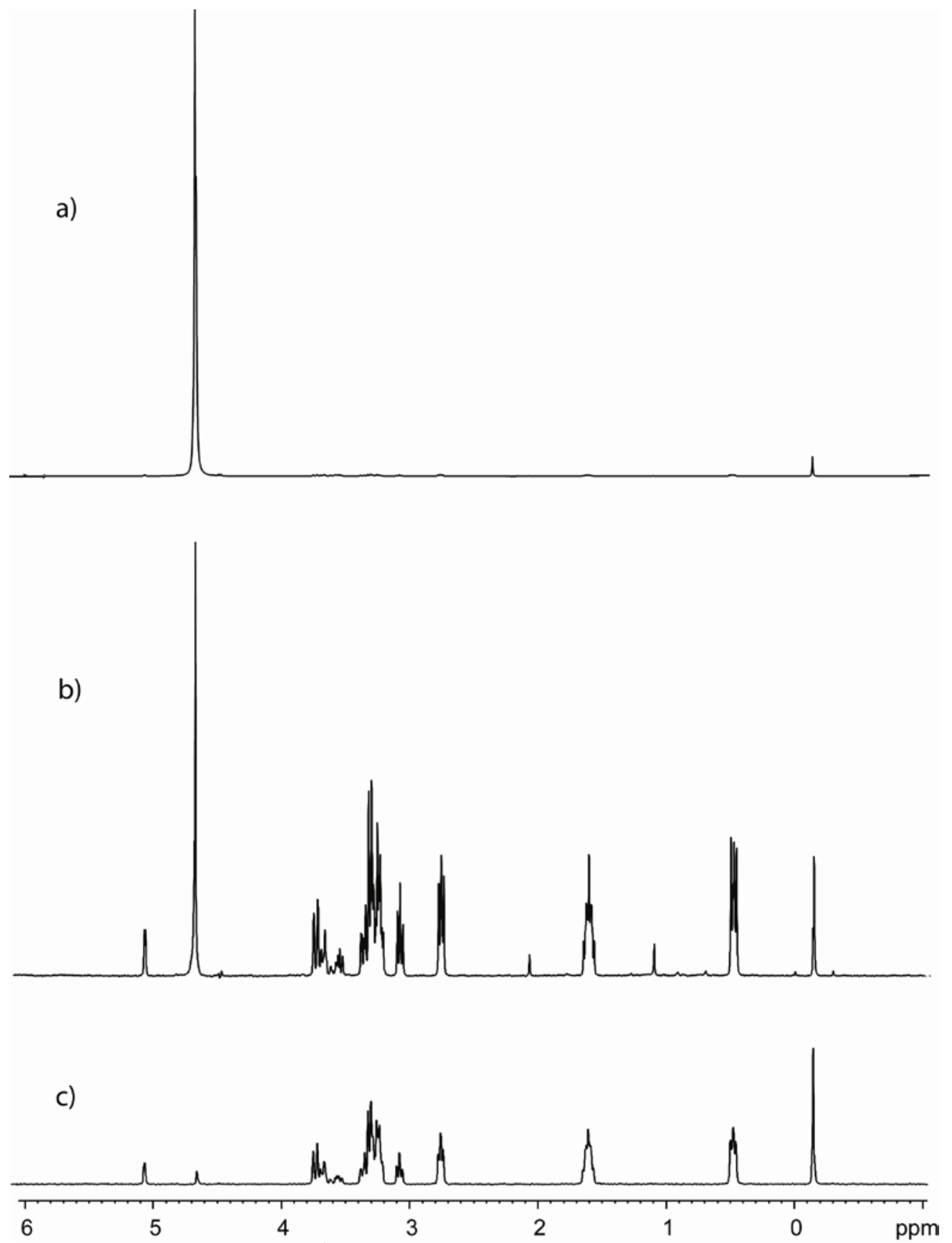

Figure 4: Comparison of ${ }^{1} \mathrm{H}$ NMR spectra acquired a) without presaturation in $2.0 \mathrm{~mm}$ OD flow cell, b) with presaturation in $2.0 \mathrm{~mm}$ OD flow cell, c) with presaturation in $1.5 \mathrm{~mm}$ OD flow cell.

\section{4. $\quad{ }^{13} \mathrm{C}$ NMR}

One of the advantages of this micro flow cell design is the ability to utilize any probe configuration such that different types of NMR experiments could be performed. As an example, the solution ${ }^{13} \mathrm{C}$ NMR spectrum of $100 \mathrm{mM}$ glucose/ $\mathrm{D}_{2} \mathrm{O}$ is shown in Figure 5. The small 
detection volume requires extensive signal averaging ( 14 hours), but does demonstrate that heteronuclear NMR can be performed on mass limited sample volumes.

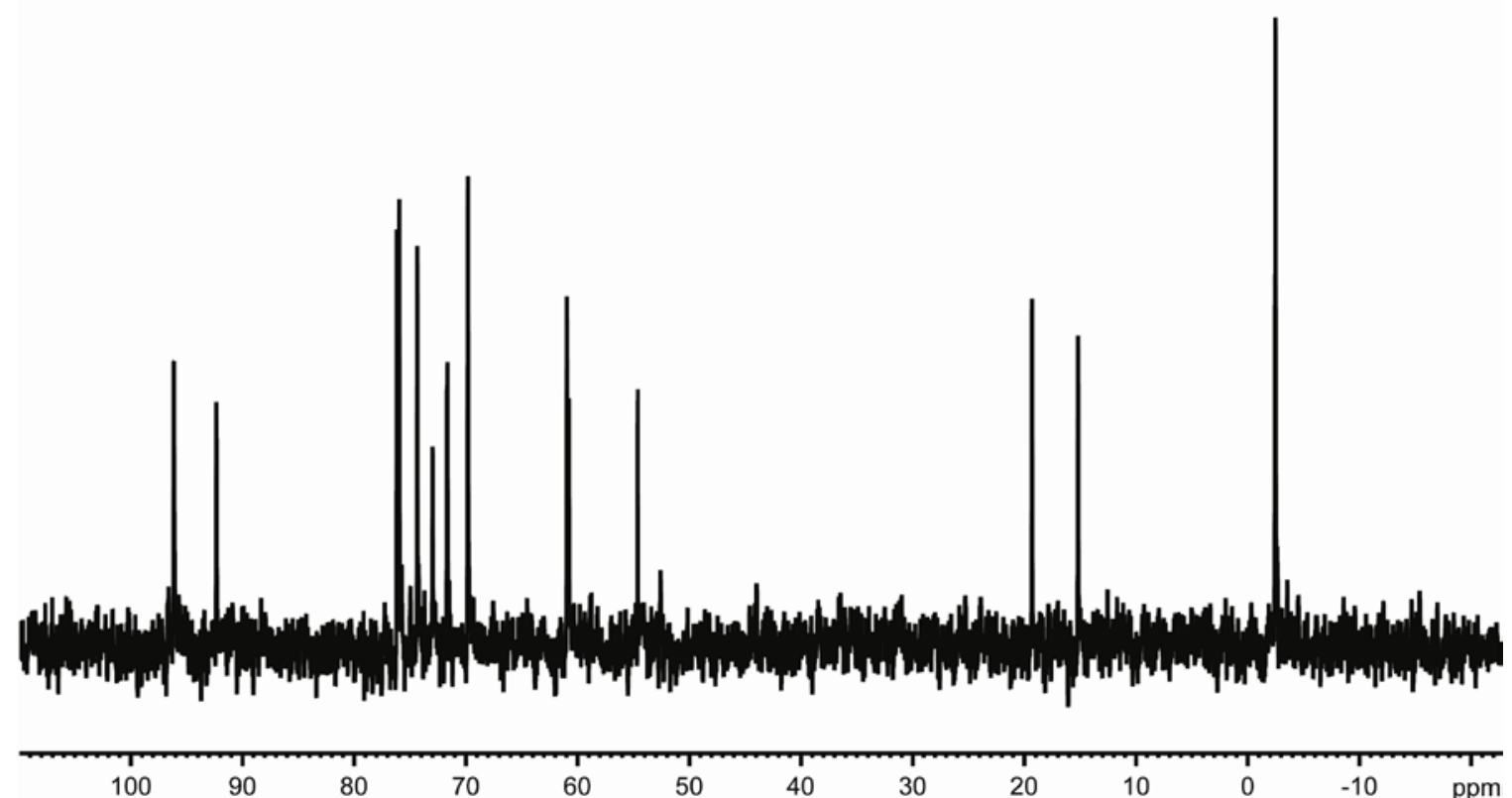

Figure 5: The ${ }^{13} \mathrm{C}$ NMR spectra of $100 \mathrm{mM}$ glucose at $150 \mathrm{MHz}$ using a $1.5 \mathrm{~mm}$ OD micro flow cell $(3.8 \mu \mathrm{L})$ on a $5 \mathrm{~mm}$ broadband probe.

\section{5. ${ }^{1} \mathrm{H}$ Diffusion Experiments}

The utility of diffusion-ordered spectroscopy (DOSY) NMR has been demonstrated for a variety of different applications, ranging from characterization of water diffusion in proton exchange membranes to identification of biological metabolites in complex mixtures by elucidation of their diffusion coefficients. Diffusion based techniques could enhance NMR analysis of mixed-analyte samples with limited sample amounts. To show that the micro flow cell developed here is applicable to such experiments spectra as a function of gradient strength for the $100 \mathrm{mM}$ glucose sample (acquired at $600 \mathrm{MHz}$ ) is shown in Figure 6. Even for these 3.8 $\mu \mathrm{L} \mu \mathrm{l}$ detect volume, the self-diffusion coefficient could be easily measured. 


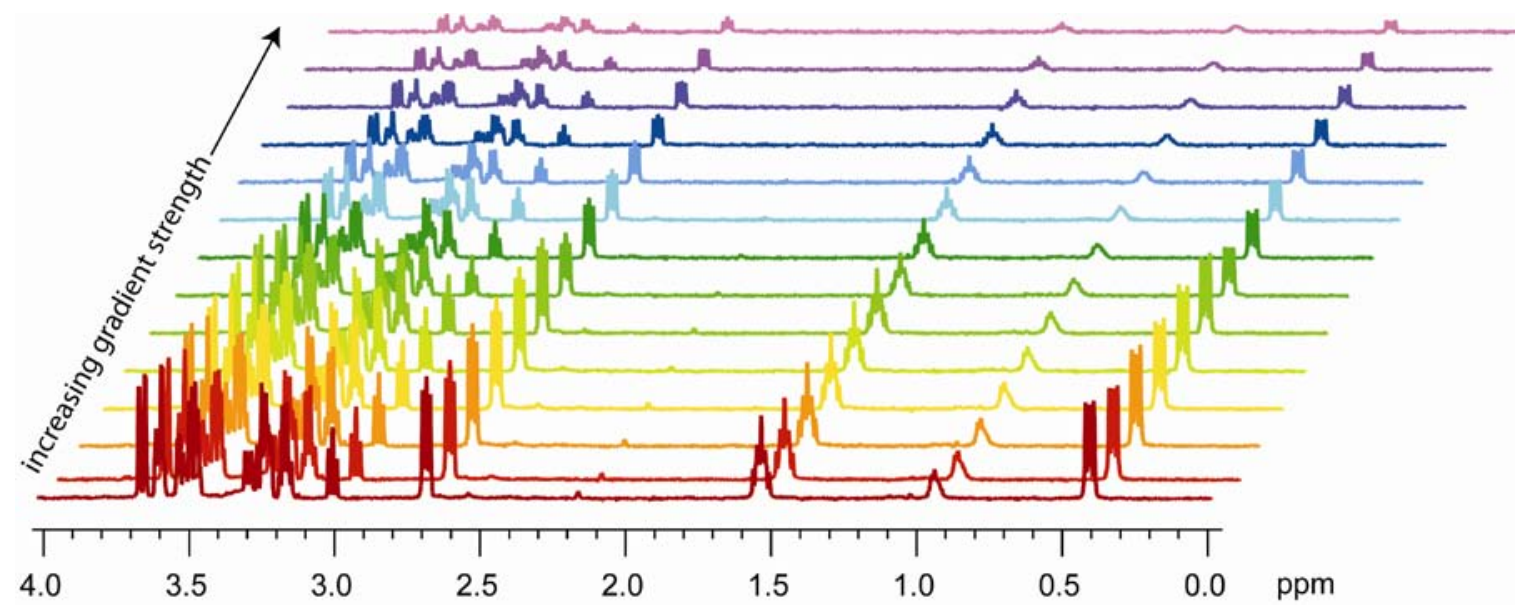

Figure 6: ${ }^{1} \mathrm{H}$ NMR $600 \mathrm{MHz}$ spectra as a function of gradient strength obtained for the $100 \mathrm{mM}$ glucose sample using a $1.5 \mathrm{~mm}$ OD flow cell on the DIFF30 $5 \mathrm{~mm}$ diffusion probe.

\section{Conclusions}

The fabrication and testing of micro flow cells for NMR spectroscopy based on a split thetacapillary design have been described. This design allows different commercial probes and instrumental configurations to be easily used as demonstrated by the ${ }^{1} \mathrm{H},{ }^{13} \mathrm{C}$ and diffusion-based NMR experiments obtained. This flow cell design is low cost and can easily be implemented in any NMR facility with standard commercial probes. 


\section{References}

1. Hatada, K., et al., On-line GPC/NMR analyses of block and random copolymers of methyl and butyl methacrylates prepared with t-C4H9MgBr. Polymer Bulletin, 1989. 21: p. 489495.

2. Hatada, K., et al., On-line GPC/NMR experiments using the isotactic poly(methyl methacrylate) with well-defined chemical structure. Polymer Bulletin, 1988. 20: p. 317321.

3. Ute, K. and K. Hatada, Analysis of polymers and oligomers by on-line GPC/NMR using a $500 \mathrm{MHz} N M R$ spectrometer as a detector of GPC. Analytical Sciences, 1991. 7: p. 16291632.

4. Robertson, D.F., J.E. Heron, and M.C. Beckett, On-line gel permeation chromatography/nuclear magnetic resonance of complex polymer formulations. Applied Spectroscopy, 2004. 58(1122-1127).

5. $\quad$ Albert, K., et al., On-line coupling of separation techniques to NMR. Journal of High Resolution Chromatography, 1999. 22: p. 135-143.

6. Korhammer, S.A. and A. Bernreuther, Hyphenation of high-performance liquid chromatography (HPLC) and other chromatographic techniques (SEC, GPC, GC, CE) with nuclear magnetic resonance (NMR): A review. Fresenius' Journal of Analytical Chemistry, 1996. 354: p. 131-135.

7. Lindon, J.C., J.K. Nicholson, and I.D. Wilson, Direct coupling of chromatographic separations to NMR spectroscopy. Progress in Nuclear Magnetic Resonance Spectroscopy, 1996. 29: p. 1-49.

8. Sidelmann, U.G., et al., $750 \mathrm{MHz} H \mathrm{HLC}-\mathrm{NMR}$ Spectroscopic Studies on the Seperation and Characterization of the Positional Isomers of the Glucuonides of 6,11-Dihydro-11oxodibenz[b,e]oxepin-2-acetic Acid. Analytical Chemistry, 1996. 68: p. 106-110.

9. Holtzel, A., et al., Separation and Characterisation of Hop Bitter Acids by HPLC- ${ }^{1} H$ NMR Coupling. Chromatopraphia, 1996. 42(9/10): p. 499-505.

10. Albert, K., LC-NMR: theory and experiment, in On-Line LC-NMR and Related Techniques, K. Albert, Editor. 2002, John Wiley and Sons, Ltd.

11. Nordon, A., C.A. McGill, and D. Littlejohn, Process NMR Spectroscopy. The Analyst, 2001. 126: p. 260-272.

12. Maiwald, M., et al., Quantitative on-line high-resolution NMR spectroscopy in process engineering applications. Analytical and Bioanalytical Chemistry, 2003. 375: p. 11111115.

13. $\mathrm{Xu}, \mathrm{F}$. and A.J. Alexander, The design of an on-line semi-preparative LC-SPE-NMR system for trace analysis. Magnetic Resonance in Chemistry, 2005. 43: p. 776-782.

14. Keifer, P.A., Flow injection analysis NMR (FIA-NMR): a novel flow NMR technique that complements LC-NMR and direct injection NMR (DI-NMR). Magnetic Resonance in Chemistry, 2003. 41: p. 509-516.

15. Rehbein, J., et al., Characterization of bixin by LC-MS and LC-NMR. Journal of Separation Science, 2007. 30: p. 2382-2390.

16. Elipe, M.V.S., Advantages and disadvantages of nuclear magnetic resonance spectroscopy as a hyphenated technique. Analytica Chimica Acta, 2003. 497: p. 1-25. 
17. Lacey, M.E., et al., Union of capillary high-performance liquid chromatography and microcoil muclear magnetic resonance spectroscopy applied to the separation and identification of terpenoids. Journal of Chromatography A, 2001. 922: p. 139-149.

18. Albert, K., On-line use of NMR detection in separation chemistry. Journal of Chromatography A, 1995. 703: p. 123-147.

19. Barjat, H., et al., Adaptation of commercial $500 \mathrm{MHz}$ probes for LCNMR. Journal of Magnetic Resonance, Series A, 1996. 119: p. 115-119.

20. Schlotterbeck, G., et al., High-resolution capillary tube NMR. A miniaturized 5-uL highsensitivity TXI probe for mass-limited samples, off-line LC NMR, and HT NMR. Analytical Chemistry, 2002. 74: p. 4464-4471.

21. Henry, I.D., et al., Design and construction of a microcoil NMR probe for the routine analysis of 20-uL samples. Concepts in Magnetic Resonance Part B: Magnetic Resonance Engineering, 2008. 33B: p. 1-8.

22. Takahashi, Y., et al., Development of an NMR interface microchip "MICCS" for direct detection of reaction products and intermediates of micro-syntheses using a "MICCSNMR". Analytical Sciences, 2007. 23: p. 395-400.

23. Shaka, A.J., P.B. Barker, and R. Freeman, Computer-optimized decoupling scheme for wideband applications and low-level operation. Journal of Magnetic Resonance, 1985. 64: p. 547-552. 


\section{APPENDIX 1}

Fabrication Drawings for Micro Flow-Through Cell
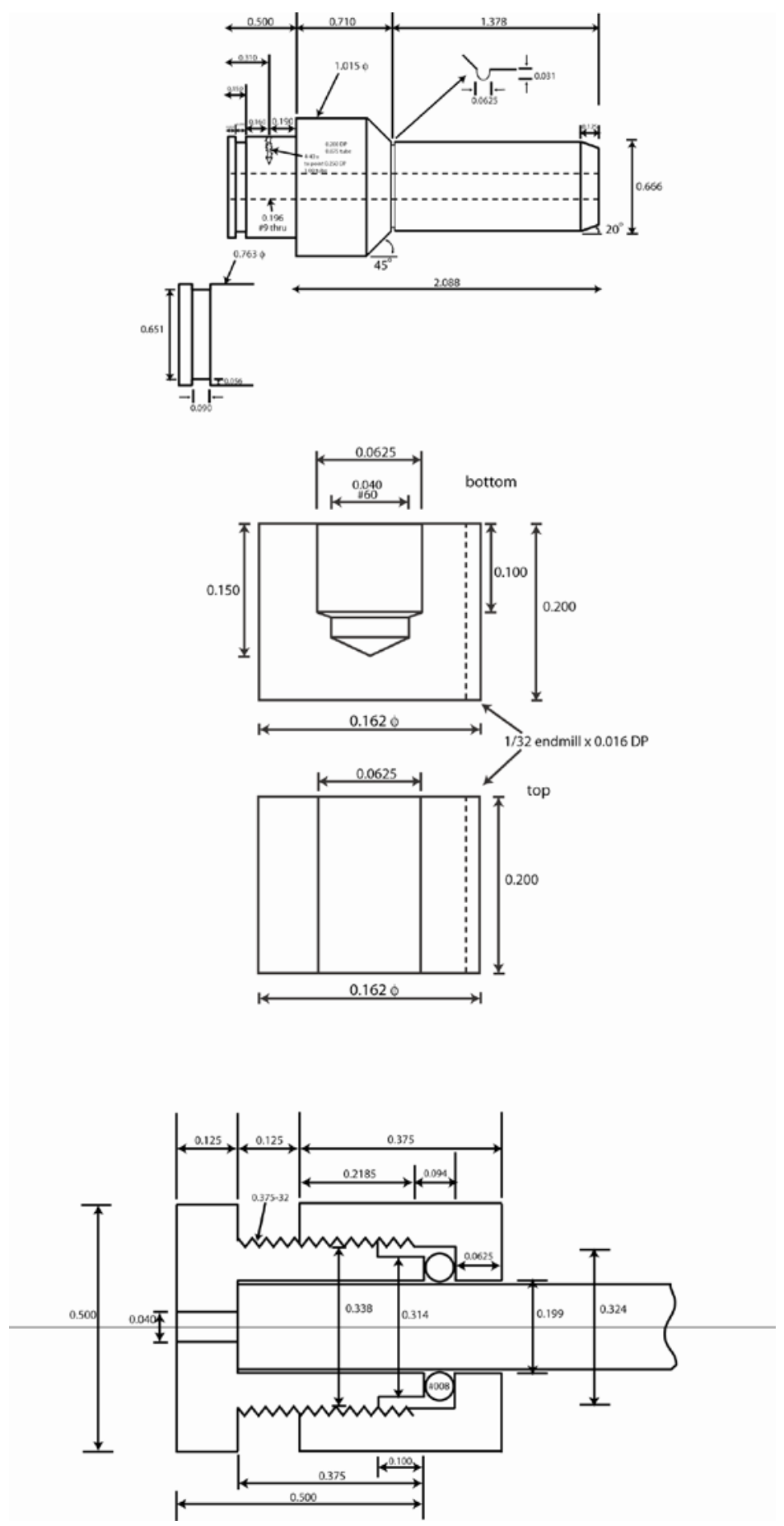


\section{Distribution}

$\begin{array}{llll}1 & \text { MS0886 } & \text { Todd M. Alam } & 1816 \text { (electronic) } \\ 1 & \text { MS0886 } & \text { Sarah K. McIntyre } & 1816 \text { (electronic) } \\ 1 & \text { MS1411 } & \text { Jim Voigt } & 1816 \text { (electronic) } \\ 1 & \text { MS1411 } & \text { Allen Rauch } & 1823 \text { (electronic) } \\ 1 & & & \\ & \text { MS0899 } & \text { Technical Library } & 9536 \text { (electronic) }\end{array}$




\section{(1) Sandia National Laboratories}

